\title{
Dual-dissociated pulmonary vein activity after pulmonary vein isolation
}

\author{
Ramon Albarran-Rincon ${ }^{1}$, Pablo Ramos ${ }^{2}$, Oleksandr Shangutov ${ }^{1}$, and Ignacio Garcia \\ Bolao $^{1}$ \\ ${ }^{1}$ Clinica Universidad de Navarra \\ ${ }^{2}$ Clínica Universidad de Navarra
}

May 19, 2020

\section{EP ROUNDS}

\section{Dual-dissociated pulmonary vein activity after pulmonary vein isolation}

Ramón Albarrán-Rincón MD (1), Pablo Ramos MD (1), Oleksandr Shangutov MD (1) and Ignacio GarcíaBolao MD PhD FESC (1).

Department of Cardiology and Cardiac Surgery. Arrhythmia Unit. Clinica Universidad de Navarra, Pamplona, Spain.

\section{Address for correspondence:}

Ignacio Garcia-Bolao. Department of Cardiology and Cardiac Surgery. Arrhythmia Unit. Clinica Universidad de Navarra. University of Navarra and School of Medicine Avda Pio XII sn. 31008 Pamplona. Spain. Email: igarciab@unav.esPhone: +34948255400 ext 4390. FAX: +34048296500

Keywords: dual-dissociated pulmonary vein activity, pulmonary vein isolation, local electrogram capture, exit-block, atrial fibrillation.

\section{Case:}

A 75-year-old male with paroxysmal atrial fibrillation (AF) underwent radiofrequency catheter ablation using high density mapping (Rhythmia). Once pulmonary vein isolation (PVI) was achieved, two simultaneous dissociated and independent ectopic rhythms were observed with the mini-basket (Orion ${ }^{\mathrm{TM}}$ ) $\operatorname{arising}^{\mathrm{from}}$ different sides of the right superior pulmonary vein (RSPV) after PVI. These rhythms could be observed in poles B to E, and poles $\mathrm{F}$ to $\mathrm{H}$ (Figure 1 ). What implications this phenomenon have?.

\section{Commentaries:}

It has been recognized that dissociated pulmonary vein activity (DPVA) is a signal of successful pulmonary vein isolation (PVI). Nevertheless, there are concerns about the possibility of AF recurrence in presence of these DPVA because of the persistence of atrial sleeves in the venous wall with automatic, slow, and less commonly, rapid and repetitive rhythm ${ }^{1,2}$. In Figure 1 there are two dissociated ectopic rhythms that demonstrated the presence of independent sleeves in the RSPV that were not conducted to the left atrium, proving exit-block. Perhaps it has been reported that DPVA may be one of the risk factor of AF recurrence ${ }^{3,4}$, however, pacing from the PV could confirm lack of conduction to LA ${ }^{5}$. In this regard, Figure 2 and Figure 3 show that the dual-dissociated activity was further confirmed by pacing, achieving local electrogram capture independently. 
There have been reported three DPVA patterns: (1) isolated ectopic beats; (2) regular ectopic rhythm; and (3) fibrillation ${ }^{6}$. To the best of our knowledge, this is the first report showing a new dissociation pattern demonstrating electrophysiologically the potential presence of independent myocardial sleeves into the PV, pointing out the importance of pacing around the whole vein regardless the presence of DPVA.

\section{References}

1. Weerasooriya R, Jaïs P, Scavée C, Macle L, Shah DC, Arentz T, Salerno JA, Raybaud F, Choi KJ, Hocini M, Clémenty J, Haïssaguerre M. Dissociated pulmonary vein arrhythmia: incidence and characteristics. J Cardiovasc Electrophysiol 2003;14:1173-9.

2. Kabra R, Heist K, Barrett C, Donaldson D, Blendea D, Beinart R, Koruth J, Singh S, Ruskin J, Mansour M. Incidence and electrophysiologic properties of dissociated pulmonary vein activity following pulmonary vein isolation during catheter ablation of atrial fibrillation. J Cardiovasc Electrophysiol 2010;21: 1338-43.

3. Doi A, Satomi K, Makimoto H, Yokoyama T, Yamada Y, Okamura H, Noda T, Aiba T, Aihara N, Yasuda S, Ogawa H, Kamakura S, Shimizu W. Efficacy of additional radiofrequency applications for spontaneous dissociated pulmonary vein activity after pulmonary vein isolation in patients with paroxysmal atrial fibrillation. J Cardiovasc Electrophysiol 2013;24:894-901.

4. Jiang CY, Fu JW, Matsuo S, Nault I, He H, Jiang RH, Liu Q, Fan YQ, Sheng X, Zhang ZW, Fu GS. Dissociated pulmonary vein rhythm may predict the acute pulmonary vein reconnection post-isolation in patients with paroxysmal atrial fibrillation. Europace 2011;13:949-54.

5. Huang S. \& Miller J. Catheter Ablation of Cardiac Arrhythmias. Elsevier; 2019. 226 p.

6. Okada M, Hirata A, Kashiwase K, Takeda, Y, Nemoto, T, Matsuo, K Ueno K, Nishimoto Y, Sugihara R, Murakami A, Ueda Y, Yasumura Y. (2016). Fibrillatory pattern of dissociated venous activity after pulmonary vein isolation: Novel characteristics for remnant foci of a trigger ectopy for atrial fibrillation. Journal of Cardiology 2016; 69.10.1016.

\section{Hosted file}

image1.emf available at https://authorea.com/users/323953/articles/452375-dual-dissociatedpulmonary-vein-activity-after-pulmonary-vein-isolation

\section{Figures}

Figure 1. High Density mapping of LA. Electroanatomic reconstruction is showed with mini-basket catheter $\left(\right.$ Orion $^{\mathrm{TM}}$ ) displayed in right superior pulmonary vein $(\mathrm{A})$. The Orion ${ }^{\mathrm{TM}}$ intracardiac signals (Poles $\mathrm{A}$ to $\mathrm{H}$ ) showed independent ectopic rhythms dissociated (arrows) from the atrial rhythm (white asterisk) (B). CS: coronary sinus.

\section{Hosted file}

image2.emf available at https://authorea.com/users/323953/articles/452375-dual-dissociatedpulmonary-vein-activity-after-pulmonary-vein-isolation

\section{Hosted file}

image3.emf available at https://authorea.com/users/323953/articles/452375-dual-dissociatedpulmonary-vein-activity-after-pulmonary-vein-isolation

Figure 2. Pacing from within right superior pulmonary vein at level of pole D showed local capture and exit block (arrows) while the second dissociated ectopic rhythm is present (white asterisk).

Figure 3. Pacing from pole $\mathrm{H}$ showed local capture and exit block (arrows) while independent and dissociated activity from pole $\mathrm{B}$ to $\mathrm{C}$ was present (white asterisk). 